\title{
Why Education in Public Schools Should Include Religious Ideals
}

\author{
Doret J. de Ruyter · Michael S. Merry
}

Published online: 29 October 2008

(C) The Author(s) 2008. This article is published with open access at Springerlink.com

\begin{abstract}
This article aims to open a new line of debate about religion in public schools by focusing on religious ideals. The article begins with an elucidation of the concept 'religious ideals' and an explanation of the notion of reasonable pluralism, in order to be able to explore the dangers and positive contributions of religious ideals and their pursuit on a liberal democratic society. We draw our examples of religious ideals from Christianity and Islam, because these religions have most adherents in Western liberal democracies that are the focus of this article. The fifth and most important section "Reasonable pluralism and the inclusion of religious ideals in public secondary schools" provides three arguments for our claim that public schools should include religious ideals, namely that they are important to religious people, that they are conducive for the development of pupils into citizens of a liberal democracy, and that the flourishing of pupils as adults is advanced by encountering religious ideals. We also offer a more practical reason: religious ideals can more easily be included within public education than religious dogmas and rules.
\end{abstract}

Keywords Reasonable pluralism - Religious ideals · Public schools · Political liberalism · Liberal · Democracy

\section{Introduction}

Public or state schools in some Western liberal democratic societies are notoriously silent on the subject of religion. Operating on a certain reading of the constitutional separation of

D. J. de Ruyter ( $\square)$

Faculty of Psychology and Education, Department of Theory and Research in Education, VU University, Van der Boechorststraat 1, 1081 BT Amsterdam, The Netherlands e-mail:dj.de.ruyter@psy.vu.nl

M. S. Merry

Faculty of Social and Behavioral Sciences, Department of Philosophy and History of Education, University of Amsterdam, Nieuwe Prinsengracht 130, 1018 VZ Amsterdam, The Netherlands 
church and state, schools are expected to be 'neutral' ${ }^{1}$ concerning conceptions of the good life. Hence, the argument runs, the best way of guaranteeing that the state does not influence its young citizens towards a particular religious view of things is to have no religion in public schools at all. Although this line of argument is logically consistent, we will defend the opposite position: religion should be an aspect of the education of pupils in public schools. The arguments for this claim do not involve the suggestion that schools should include religions uncritically or that every aspect of every religion prevalent in society should be covered in its curriculum. Neither will we defend the view that schools should aim to strengthen religious adherence amongst their pupils. Our claim is that there is at least one aspect of religions that public schools should address, namely the ideals that are fostered within religious traditions and which believers adhere to and pursue. We will show that if public schools offer pupils the opportunity to learn from a diversity of religious ideals they contribute to one of the important aims of education in liberal democracies, i.e. that pupils become reasonable citizens, ${ }^{2}$ and that they are able to do so without advocating a particular conception of the good life.

Yet we knowingly enter a crowded field of inquiry, for there is a long-standing discussion about religion in schools, separate schools, state-funding of separate schools in both Europe ${ }^{3}$ and North America. ${ }^{4}$ Contributors to the debates come from different academic backgrounds-philosophy of education, practical theology or political philosophyand address different topics. Some have questioned whether religious education simpliciter or religious schools can be justified (see McLaughlin 1984, 1985; Callan 1985; Dwyer 1998; De Ruyter and Miedema 2000; Hand 2004). Others have addressed the question of whether or not religious education and civic education are compatible (see Gutmann 1995; Macedo 1995), and, if they are, what sort of virtues religious schools promote (see Callan 1997; Spinner-Halev 2000; Gardner et al. 2002; Feinberg 2006; Merry 2007). Still other debates include the distinctiveness of separate schools (see Bryk et al. 1993; McLaughlin 1996; Conroy 1999) and whether or not religious views ought to be given 'equal time' in the classroom, etc. (see Nord 1995; Pennock 2007). We will set these and many other debates aside in order to concentrate on religious ideals in public schools.

We have several reasons for defending our focus on religious ideals. First, for persons of faith, religious ideals are one of the most important sources of meaning and therefore constitute an important part of their identity that schools in multicultural societies are

\footnotetext{
1 Although public schools are neutral towards religions, they are not neutral per se, nor should they be. As instruments of the state, public schools have an important function to play in promoting specific kinds of civic virtue.

${ }^{2}$ We shall have more to say about reasonableness below, but briefly by reasonable we mean that persons are prepared to respectfully listen to and interpret what others have to say, as well as propose fair terms of cooperation with others with whom one may not agree.

${ }^{3}$ For an overview of ideas about or practices in religious education in Europe see for instance Leicester et al. 2000 or Jackson et al. 2007.

4 It should be noted, however, that the debate among educators and philosophers of education in North America has focused primarily on fundamentalist or orthodox religious communities and families. This is understandable, because these believers tend to draw most public attention hrough court cases (the Yoder case or the Mozert case) and because they tend to be opposed to mainstream liberal views and scientific theories. There is, however, a disadvantage to this focus on fundamentalist and orthodox communities. Fundamentalists and orthodox believers represent only one group within the enormous diversity of religious persons, and quite a distinct one. This means that the discussion about inclusion of religion in schools runs the risk of being too narrow in focus. In Europe, this focus is less prevalent, although it is interesting to note that in debates about schools in France, a country whose public school system is also strictly secular, conservatives-Muslims in this case-form the center of attention.
} 
called upon to recognize (see Salili and Hoosain 2006). Second, as we will argue, being a citizen in a liberal democratic society requires particular dispositions as well as knowledge and understanding. Children are more likely to develop into reasonable liberal democratic citizens when they possess an understanding of the ideals that motivate the actions of other citizens. In other words, we believe it is less important that children know about the practices and central dogmas of the main religions in their society, than that they understand the ultimate motivations of other people, i.e. the ideals to which fellow citizens aspire. Third, we will argue that the possibility that children will flourish as adults is advanced by offering them a variety of ideals to examine and consider (see also Levinson and Levinson 2007; De Ruyter 2007). Religious ideals provide a valuable source of alternative views on what contributes to a flourishing life. ${ }^{5}$

Finally, there is a practical reason, which may nevertheless be a convincing argument concerning why public schools should include religious ideals in their curriculum. It seems clear to us that religious ideals can more easily be included within public education than religious dogmas and rules. Ideals, as we will explain, are typically abstract in character and therefore are open to personal interpretations of those who subscribe to the idealalthough we will show that ideals may lose this character, too. The openness of ideals has two important advantages. First, it gives them the potential to function as bridges between persons and their community and those who have attachments to different communities. Second, while the value of ideals can be discussed (see for instance Noddings 1993) or their importance can be scrutinized, they do not lend themselves to an examination of the epistemological basis or truth claims of religious beliefs in public schools as some propose (see Rosenblith 2008; Rosenblith and Priestman 2004). In our view, such discussions certainly have their place, but a number of conceptual and logistical obstacles in schools stand in the way of this happening. ${ }^{6}$ Therefore, our more modest claim is this: to become good citizens, pupils must understand what inspires and motivates other people. Moreover it is important that they are offered the opportunity to discover whether or not there is a possible value in religious ideals for them too - which, as we will explain, does not mean that they ought to become religious persons themselves.

We circumscribe our discussion in at least three ways. First, the relevant contexts in this article are Western liberal democracies. Our arguments will primarily pertain to North America because the place of religion in public schools is more openly contested there. While European religious piety (at least among Christians) has been in decline since the 1960s, a large percentage of the North American population, particularly in the United States, continues to be religiously devout. Consequently, appeals for including religious ideals in public schools have particular resonance. However, our arguments are not limited to North America; indeed, they also broadly pertain to the European context, because while religious education is widely on offer-indeed, outside of secular France, some religious

\footnotetext{
${ }^{5}$ Briefly, people are able to lead a flourishing life if they give personal meaning to the objective goods that are good for all human beings, for instance health, relations, creative and intellectual development, and if the life that follows from this is satisfying to them. We will return to this in the section "Reasonable pluralism and the inclusion of religious ideals in public secondary schools".

6 Proponents of epistemic analysis will no doubt object to this, claiming that we are exempting religious truth claims from rational analysis and engaging in some kind of multicultural moral relativism. Yet we would argue that conceptually religious truth claims by their very nature are non-rational and therefore are not amenable to rational analysis. Further, the difficulties both with respect to adequate (and unbiased) teacher training and parental objections to epistemological analysis of their faith claims in classrooms surely must give us pause.
} 
instruction is mandated ${ }^{7}$ by the state-its focus most of the time is decidedly Christian in character, thus excluding most non-Christian religious ideals. In fact, the virtual absence of non-Christian religious instruction in most non-religious schools in Europe has precipitated repeated calls for separate religious schools in order to address what parents claim are the spiritual needs of pupils. Thus our argument for the inclusion of religious ideals in public education implies the inclusion of Islamic, Hindu, Buddhist, Jewish, etc. ideals. Second, while the arguments we develop in this article apply to all schools, our focus is on public or state schools. Denominational schools can reasonably be expected to offer a variety of religious ideals too, but because their position with regard to religion(s) is profoundly different from public schools we will not pursue that line of defense here. Third, our arguments apply to high schools or secondary schools, because they assume particular cognitive capacities that children at primary school age do not normally possess.

Finally, it is necessary that we are selective in our examples of specific religions. In Western liberal democratic societies the two religions with the most adherents are Christianity and Islam. To be sure, Christianity has enjoyed an historically privileged position in Western society, and other important differences are salient (e.g., Muslims do not comprise a socioeconomic underclass in North America). However, in our age of socalled 'global terror', Muslims in both North America and Europe receive a lot of public attention. Particularly on continental Europe, the fear of so-called Islamization of society has led to a significant increase of - primarily negative-attention in the media and politics. Therefore, with regard to the position of religion in the public domain and public schools, our examples in this article are drawn from these religions and our arguments also are illustrated by reference to these two religions.

Before we can begin with addressing the central question, we will first elucidate the meaning of 'religious ideals'. In the sections "Religious ideals in the public domain" and "Reasonable pluralism and religious ideals", we will then address the more general question of whether or not religious ideals have a role to play in the public domain and how this role may be evaluated. In the section "Reasonable pluralism and the inclusion of religious ideals in public secondary schools" we will provide arguments for including religious ideals in the curriculum of public schools and we end with a concise conclusion.

\section{Religious Ideals}

Religious ideals can be defined as ideals that acquire meaning due to a belief in something transcendent or a divine being (De Ruyter 2006). This means that only ideals that are related to a religious conception of the good are called religious ideals and that they are exclusive to those who adhere to such a conception. ${ }^{8}$ Thus, we reserve the term religious ideals for those with beliefs in something transcendent and only for those ideals that are related to their beliefs. This gives rise to two kinds of religious ideals. The first type may be called religious ideals in the strict sense and consists of ideals that are constituted by a

\footnotetext{
7 Of course, there are usually opt out provisions in place, and in some countries ethical instruction of a nonspecific sort may be substituted for religious education.

8 'Religious ideals' is the generic name of a category consisting of a wide range of specific religious types of ideals, for instance Christian, Islamic, Buddhist, Hindu, Sikh, Bahai' ideals. And it might be argued that these labels are still too general. For instance, Christianity (like many other religions) is a highly diversified religion, which may even make it impossible to speak about 'Christian ideals'. Rather, one may wish to use terms like Roman Catholic ideals, Eastern Orthodox ideals, Wesleyan ideals, Reformed ideals, etc, though of course one will find various subsets within each of these traditions as well.
} 
belief in a transcendent being. These ideals are oriented towards the divine or are characteristic of one's relation to the divine. Such ideals are only pursued by people who believe in something transcendent or a transcendent being; the ideals have no meaning beyond this faith. For instance, the ideal of a devout Christian may be to live up to the commandments of God. The second type of religious ideals refers to religious ideals in the broad sense. These ideals belong to other domains of life, i.e. the moral, social, economic, political or aesthetic domain, but these ideals get a specific religious meaning through the belief in a divine being. For instance, the aspiration of being a good Christian or a good Muslim is translated into ideals regarding the way in which society is best organized, the economy is ideally run, etc. The relationship between the religious and other domains is normally an iterative one, i.e. the way in which people conceptualize their ideals is based on a mutual influence. We do not wish to suggest that the religious domain is necessarily foundational for the other kinds of ideals, although for some groups, most particularly fundamentalist believers, this will be the case.

Religious ideals are a type of ideals and therefore we also have to describe the concept of 'ideals'. We define 'ideals' as those values that people believe to be excellent or perfect, to which they attach high importance, and that have not been realized as yet (De Ruyter 2003, 2007). Put differently, ideals are imaginations or visions of situations or personal characteristics that the person who has the ideal believes to be excellent or perfect and to which she attaches high value. The images tend to be open to diverse interpretations, for they refer to visions of traits of character and situations that are not precisely defined and therefore persons find it necessary to give their own interpretation to the ideal. We can illustrate this by examining a small section of the diversity of conceptions of religious ideals found in Christianity. Christians are called upon by Jesus in his Sermon on the Mount to be as perfect as God is (Matthew 5: 48), which includes relating to one's enemies with charitable love (agape) and forgiving the offending other as much as "seventy times seven." However, the characteristics that are ascribed to God in the Bible are highly diverse, for instance that $\mathrm{He}$ is all-knowing, righteous, jealous, immutable, forgiving, vengeful and merciful. Similarly, what characterises heaven and the ways in which Christians pursue the situation they call heaven, may also be very different. Further, it is also clear that Christians have different and even conflicting views on what constitutes an ideal society or ideally run economy, for Christians can be found on the (far) left and (far) right of the political spectrum. And finally, Christ's commandment to make disciples of all nations (Matthew 28:19) has been interpreted in a variety of ways, from Christopher Columbus' violent and exploitative colonisation and Christianization of indigenous peoples, to the arguably selfless work of Mother Theresa in the slums of Calcutta. ${ }^{9}$

But before we go any further, we will briefly elucidate the distinction between religious dogmas and rules which we referred to in the introduction. We will mention three important differences. First, religious ideals are open to a personal interpretation by believers, while dogmas and particularly rules are laid down in relatively precise terms that the believers are expected to adopt. Phrased in terms of Nicholas Rescher (1987, p. 122): ideals are the spirit of the law, while rules and regulations are the letter of the law. Of course, this description is crude and should be nuanced, but it is helpful for a good understanding of what religious ideals are. The nuance with regard to ideals is for instance that there are boundaries to the personal interpretation one may give to religious ideals, because they also have a communal character: religious ideals arise out of a shared social

\footnotetext{
9 Although there will be those who would argue that she was not actually doing selfless work, but was merely working out her own salvation.
} 
practice within a community of believers. Not every personal interpretation will be recognised as a version of the communal religious ideal. For instance, most Christians would not recognise a hedonistic world in which everyone aspires to have as much fun as possible as they would an eschatological ideal of heaven on earth. On the other hand, dogmas and rules are not as unalterable as they may seem. Throughout history, religious communities have altered their rules and requirements and dogmas have evolved over time. Furthermore, each differs in importance; while disregarding a more peripheral rule is normally not a reason for exclusion, breaching central dogmas may indicate that a person no longer perceives himself to be a member of the religious community. However, this is possible precisely because dogmas and rules operate rather differently, and the importance ascribed to each varies.

Second, ideals belong to the aspirational domain, while dogmas and rules belong to the domain of duties. ${ }^{10}$ Rules and dogmas describe what people must do or believe if they are to meaningfully adhere to a particular faith. For instance, ordinarily Muslims are required to follow the five pillars of Islam, i.e. to fulfil the five duties-among which are daily prayer, giving alms, fasting during the Ramadan-if they want to be considered good Muslims; Christians are expected to believe that Jesus is the son of God. Religious ideals, on the other hand are aspirations that aim for an optimum outcome. Believers cannot be obligated to pursue religious ideals, because ideals reach beyond what may be required of people; they refer to excellences to which people aspire, not to expectations people have to pursue.

Finally people are intrinsically motivated to pursue an ideal. While they can follow rules for extrinsic reasons, for instance because they want to belong to a religious community or participate in its rituals, they pursue an ideal because they are convinced of the excellent qualities to which the ideal refers. Therefore, religious ideals, and not dogmas, will often tell us more far more about a person.

The combination of the high importance attached to the ideal and the supremacy of the value the ideal refers to motivates individuals to pursue their ideals. This makes ideals a powerful source of meaning and action. However, ideals-including the ways in which they are pursued—can be good or evil, as we will argue in the next sections.

\section{Religious Ideals in the Public Domain}

Religious ideals in the broad sense comprise religious conceptions of political and moral ideals, which per implication means that religious views have a bearing on discussions in the public and political domain. A lot has been written about religion in the public and political domain and therefore we will only briefly describe three possible evaluations of religiously influenced moral and political ideals in the public and political domain within Western liberal democracies.

The first evaluation of reference to religious ideals in the public domain is a negative one: religious ideals undermine social cohesion and, therefore, are disruptive to political stability. Religious ideals can be understood as having two characteristics that may more easily give people the justification to impose their ideals on everyone: (1) they are sanctioned by an unquestioned authority and (2) they are believed to be in the best interests of all-whether in this life or in the afterlife. Because some religious groups operate on the

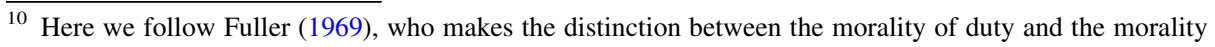
of aspirations. 
force of these convictions in their attempts to convert others, including the use of political power to impose those convictions, it is argued that allowing reference to religious ideals in the public and particularly the political domain undermines the existence of a peaceful pluralistic society. This will be difficult to deny when religious ideals require that all humans need to be converted by whatever means necessary. In these instances, ideals may indeed prove to be highly dangerous.

History has given us myriad examples as evidence that religious ideals impel some people to become religious extremists and recent examples are not hard to come by either; presently most western countries have installed special (intelligence) organizations to combat the threat of religiously-inspired terrorism. Even when religious ideals do not necessarily lead to extremism, they can encourage oppression of those who hold alternative views. This is particularly the case when ideals become concrete blueprints that are thought to be realizable. Emmet (1994) has eloquently described the difference between two conceptions of ideals. Regulative ideals do not describe a practice or society in precise detail like blueprints, but offer a standard for a practice. Furthermore, while regulative ideals are perceived to be unrealizable, blueprints are presented as an achievable states of affairs. Finally, regulative ideals orient a practice, whereas blueprints prescribe what should be thought and done (1994, p. 17). When religious ideals of an ideal society become utopian blueprints, religious adherents may try to realize the utopia by whatever means available to them; if the ideal society can be realized, the end may well justify all means.

However, the second evaluation is that religiously inspired ideals can have a positive influence on society, because they offer an alternative voice that can make a constructive contribution to discussions of social or political import. In addition to being self-regarding, many religious ideals are other-regarding (as well as Other-regarding). This ethical dimension of religious ideals can have a positive influence on the ways in which societies function. In some cases, the voice of religion may even buttress the most reasonable arguments on offer concerning human rights and dignity, which, for example, occurred during twentieth-century freedom struggles in India and the United States. Yet one does not have to think of moral paragons such as Mahatma Ghandi or Martin Luther King Jr.; there are also other, less renowned, religious persons and groups that feed and shelter homeless people, offer drug counseling, employment assistance, etc.

Both of these evaluations can be accused of one-sidedness or of being simplistic, for it is obvious that the positions can defeat one another by the examples and arguments they each provide. Yet a third evaluation can be positioned in the middle. This evaluation does not deny the importance of religious ideals for people, but merely states that they cannot be a basis for public or political law. An example of this position is Rawls' idea of the overlapping consensus. According to Rawls $(1987,1989,1993)$ it is unreasonable to impose a comprehensive doctrine like religion on all citizens of a society. Rather, the basic structure of a society should be founded on "fundamental ideas we seem to share through the public political culture" (1993, p. 150). Reasonable principles are (1) those which are accessible to reasonable persons and which facilitate willing consent, and (2) those which are consistent with fair terms of cooperation and free and equal citizenship. Rawls ascribes two qualities to a reasonable person, namely that they are "ready to propose principles and standards as fair terms of cooperation and to abide by them willingly, given the assurance that others will likewise do so" and "that they are ready to discuss the fair terms others propose" (1993, p. 49). These two qualities are also articulated as two moral powers: a capacity for a sense of justice and a capacity for a conception of the good.

As an ideal, reasonable pluralism describes a society, comprised of many conceptions of the good, in which reasonable persons, as citizens, willingly support a political conception 
of justice that is not grounded in comprehensive truth claims but by principles they may endorse in light of their common human reason. So a well-crafted political conception of justice that governs the basic structure of society will function independently of comprehensive doctrines. Of course this does not mean that a political conception of justice cannot fit into or be supported by various reasonable comprehensive doctrines. Thus, significantly, one's religious conviction is not excluded from the public domain in the sense that it may be one of many good reasons for supporting the non-comprehensive political conception of justice. As Rawls suggests, "It is left to citizens individually to decide for themselves in what way their shared political conception is related to their wider and more comprehensive views" (1989, p. 249).

The middle position is not neutral vis-à-vis all religious ideals, for then it would be a version of the second (positive) evaluation. It does place limits on the acceptability of positions and the way in which they are pursued (see for instance Macedo 2000; De Jong and Snik 2002). For instance, it requires that principles of toleration and recognition as well as the harm principle necessarily apply. That is, individuals and the communities to which they belong may not act upon their ideals in ways that harm others (physically or psychologically), including fellow group members. Further, internal restrictions must be challenged that unduly limit the exercise of free will or which impose unfair restrictions on exiting a community (Spiecker et al. 2006). Determining what constitutes 'unfair' will invariably require examining specific cases but we can outline minimal prerequisites such as that children especially require the resources-beginning, importantly, with an education-to develop their capacity for making deliberative judgments and acting upon those judgments without fear of reprisal, even (or, perhaps especially) in cases of apostasy. Developing such capacities necessarily excludes practices like indoctrination or brainwashing that aim to establish precisely the opposite effect (see Merry 2005). Thus, some ideals will more comfortably 'fit' within reasonable pluralism's demands, while others will ostensibly be squeezed out, or, at least be made to feel less welcome.

Even though the principles of reasonable pluralism cannot include all ideals of all citizens, we still maintain that the principles of reasonable pluralism serve a pluralistic society in the best way. Pluralism in western societies is a fact, which can be lamented or applauded, but it is the situation in which people in Western societies live. The best type of organization of pluralistic societies is one that allows all people to flourish by giving meaning to their lives on the basis of the ideals they value. Yet this is an arrangement that is impossible to realize, because the ideals of some may inhibit the pursuit of ideals of other citizens, and ideals should therefore be interpreted as a regulative ideal. Thus, a society should be organized in such a way that citizens can aspire to the regulative ideal in conjunction with giving meaning to their own lives on the basis of their private ideals. We suggest that reasonable pluralism is the best way of doing so, because well-crafted public policies will not be based on a particular conception of the good life that coerces citizens to comply without their consent. Moreover, reasonable pluralism encourages citizens to reflect upon the best way in which a pluralistic society can include the diversity of ideals. In other words, reasonable pluralism offers the best opportunity for citizens to evaluate policies and practices in the public domain by means of the regulative ideal that everyone will be able to flourish.

Nevertheless, it might be argued that reasonable pluralism is unjust, because it is intolerant towards people who adhere to (religious) ideals that do not cohere with reasonableness. Moreover, education congenial to reasonable pluralism, which requires that children learn that they need to complement their religious ideals with reasonableness in the public domain, may have the consequence of placing some in conflict with their 
religious ideals. Consider how many deeply religious persons feel profoundly uncomfortable with the manner in which pluralism appears to govern public life. Seemingly endless choices and opportunities provide little comfort to those whose ultimate religious ideals decisively trump other ideals. Indeed, reasonable pluralism is believed by some (Holmes 1995; Tarazi 1987; Yousif 2000) to be a type of moral relativism that has an intentionally eroding effect on their cultural or religious ideals. ${ }^{11}$ Such beliefs may induce some to withdraw from the public sphere, or others to banish them from democratic conversations. Yet this would be an unfortunate outcome, as Strike (2007, p. 707) reminds us:

[D]emocratic conversations that seek common ground cannot begin by excluding a whole genre of widely held views from serious discussion. Moreover, the attempt to exclude has tended to cause the expression of such views to go underground where they gain strength, go unrebutted and emerge in aggressive and theocratic forms. It is both more principled and strategically wiser to invite advocates of such views to the conversational table.

It is true that the principles of reasonableness are not neutral against every position, but this does not necessarily make them unjust. This would only be the case if they conflict with pursuing the regulative ideal of a society in which everyone can flourish. Since the opposite is true, sufficient reasons exist for defending reasonable pluralism as the best organizing principle of a pluralistic society. Thus, reasonable pluralism is the background against which we aim to defend the position that religious ideals be included in the curriculum of schools. The three evaluations offered above have shown that it is necessary to make a distinction between two aspects of religious ideals: the ideals themselves can be evaluated with regard to their compatibility with the ideals of a liberal democracy and the way in which they are pursued can be scrutinized. Before we address this topic, we first want to give a more precise account of the ways in which religious ideals and the ideals of reasonable pluralism may be compatible or incompatible.

\section{Reasonable Pluralism and Religious Ideals}

The former section has not settled the matter of precisely how religious ideals can best be voiced within the public sphere, or, for that matter, whether all religious ideals are compatible with reasonable pluralism. We suggest that there are three possible evaluations, both with regard to the ideals as well as their pursuit: they can be complementary to, neutral, and opposite to the ideals of a liberal democracy.

Some religious ideals are complimentary to the purposes of the liberal state. Indeed, far from being inimical to the interests of the public, some religious ideals may be perfectly compatible with liberal notions of citizenship such as equality of persons, individual autonomy and freedom of expression. Though sometimes expressed differently religious ideals may nevertheless extend the language of reasonable pluralism in useful ways. A powerful example of such an ideal is 'all people are equal in the eyes of God' that Christians profess, which complements the liberal right to non-discrimination. Another one would be 'to love your neighbor as yourself', which is consistent with the liberal notion of

\footnotetext{
11 Importantly, when this perception is aggravated by unfavourable economic circumstances and social exclusion, conditions may be ripe for strengthening less tolerant religious ideals that militate against those prized by liberal democratic states.
} 
reciprocity. Most Christian ideal characteristics of a person are also complementary to those valued in liberal democracies. We have already mentioned ideals like being righteous or just, humble, merciful and charitable. Each may contribute to a flourishing liberal democracy. That these ideals are not unique to Christianity may be offered as a further illustration that religious ideals can be compatible not only with other religious ideals but also to the presumed secular ideals of the liberal democracy and reasonable pluralism.

The same may be said of Islam. For the majority of Muslims in the West, Islamic ideals and practices normally do not conflict with the ideals of reasonable pluralism. Similar to our Christian example, most Islamic and liberal ideals have a complementary relationship, and Muslims normally support the political institutions that help to make their life a rather good one (see Malik 2001, 2004; March 2006). The pursuit of religious ideals that are complementary can also be conducive to a flourishing liberal democracy. If religious ideals are voiced reasonably they can keep alive the critical debate amongst citizens about what constitutes an ideal liberal democracy and in which ways liberal societies fall short. This certainly happens when Muslims challenge various types of discrimination, or push for positive freedoms, including the right to bury their dead or slaughter animals according to Islamic custom, or work to advance legislation in order to receive equal treatment in establishing Islamic schools. To be sure, Muslims who exercise their political will in this way are voicing an alternative to the prevailing practices that favour certain (normally Christian or secular) institutions; however, they are doing so in a manner that is consistent with deliberative democratic ideals and the requirements of reasonable pluralism. Hence, when religious ideals enter the political arena in this way, there is potentially real fruit to be borne.

Religious ideals that are politically neutral comprise only a small group. They primarily consist of religious ideals in the strict sense, i.e. ideals that are oriented towards the divine or are characteristic of one's relation to the divine. Normally these ideals principally affect one's private life and one's (personal) relation with a transcendent being and are therefore neutral with regard to the public domain. However, this is not necessarily the case, for even personal ideals can also have a bearing on convictions that shape the way in which people act in the public domain. For instance, trying to live up to the commandments of the divine will likely have an influence on the way in which adherents look upon others. To take an extreme example we could mention the Phelps, an extremist Christian family living in Westboro, Kansas. Their religion is particularly toxic, for owing to their immovable convictions they have been known to organize pickets at funerals of soldiers who have fallen in the Iraq war at which they tell the world that God hates America because the US, in their view, loves homosexuals. ${ }^{12}$ Although their hate campaign falls under First Amendment protections of free speech-and thus is permissible within the bounds of a liberal democracy ${ }^{13}$ because they do not physically attack other people or incite others to do so-their ideals, including the way in which they pursue them, are not neutral to the ideals of a liberal democracy. Neither, for that matter, are they consistent with the requirements of reasonable pluralism.

However, the pursuit of religious ideals can be neutral to the public domain while the ideals themselves are not. Some are devout believers as well as convinced liberal

\footnotetext{
${ }^{12}$ For more information about the Phelps family, we can refer the reader to their website: http://www.godhatesfags.com/

13 While all liberal democratic constitutions make provisions for criminal action to be taken against defamation and the incitement to riot, exactly what constitutes hate speech, and thus what will be publicly tolerated, will vary from one liberal democratic context to another.
} 
democrats. While they may personally believe that divorce that is not annulled by the Roman Catholic Church is immoral or that homosexuality is an abomination, they are also committed to the liberal democratic ideal that everyone should be able to live their life as they see fit and therefore oppose any kind of discrimination on the basis of their private moral convictions. Notice that this pursuit of religious ideals is consistent with the requirements of reasonable pluralism.

Finally, some religious ideals, including the way in which they are pursued, are opposed to those of reasonable pluralism. When religious ideals are perceived as blueprints and thereby cease to be tolerant, it seems they necessarily collide with reasonable pluralism, because being reasonable not only assumes that one is able to revise one's ideals, but also that others are entitled to espouse beliefs - and in most instances act upon those beliefs-with which one does not agree. The ideal of a theocracy is clearly in conflict with the ideals of a liberal democracy, but so are ideals that lead believers to discriminate against others because of their utter contempt of the other's political views, religion or sexual identity.

For example, a political understanding of religious ideals impels some Muslims not only to prioritize the global Muslim community (ummäh) but also to view liberal democratic political institutions with utter contempt. Muslims who assimilate themselves to Western institutional norms (e.g., military service, jury duty) are believed by some to be betraying their Islamic faith, particularly if they are called upon to fight or testify against other Muslims. Taking matters further, residence in non-Islamic lands for a few has a tactical side, one that is driven by ideals which seek to establish an Islamic state (see Abbas 2007; Choudhury 2007; Husain 2007). Though only endorsed by a small minority, some Muslims believe that submission to non-Islamic authorities, with no consideration for Islamic law (shari'ah), makes the pursuit of specific Islamic ideals impossible. Clearly, these political ideals would not count as reasonable comprehensive doctrines on any reading of reasonable pluralism not only because such ideals offend against the principles of toleration or mutual respect; they also directly threaten a number of social goods that political liberals support, including legitimacy, reciprocal trust, tolerance, and political stability.

Thus, religious ideals may be compatible, or they may collide, with the ideals of reasonable pluralism, which indicates that reasonable pluralism is not an intolerant or anti religious doctrine, but is in fact a middle position. This implies that education consistent with reasonable pluralism in public schools need not exclude the possibility of incorporating religious ideals in their curriculum. On the contrary, the discussion in this section has corroborated our reasons for claiming that religious ideals should be part of the education of pupils in public schools. First, for those whose religious ideals are compatible with reasonable pluralism it is important that their ultimate values are recognized in public schools and accepted as a source of inspiration to foster the ideals of reasonable pluralism. Secondly, it is beneficial to the flourishing of a liberal democracy that future citizens learn to make nuanced evaluations about conceptions of the good life for themselves and other citizens. Teaching children about the positive influence of religious ideals as well as their dangers is arguably conducive to their development into reasonable citizens.

Of course, our proposal will not be agreeable to those whose religious ideals are incompatible with the ideals of reasonable pluralism. This is unavoidable, but we have already argued that this outcome is not unjust given the educational and societal benefits that accrue to others, including the children of those who espouse 'unreasonable' ideals. 


\section{Reasonable Pluralism and the Inclusion of Religious Ideals in Public Secondary Schools}

In the introduction we argued that entering the broader discussion of religion in the public school through the door of religious ideals may shed some different light on this discussion. We aim to show in the remainder of this section that a focus on religious ideals both in a strict and broad sense does indeed make a novel contribution to the debate about religion in public schools.

In the former sections we have shown that religious ideals can be given a place in the public domain, but it also became apparent that not every religious ideal or every way of pursuing religious ideals is compatible with the ideals of reasonable pluralism. In this section we return to three reasons for including religious ideals in public schools we gave in the introduction, leaving the fourth practical reason aside, and will investigate their validity in light of the conclusions of the former sections. First, we will ask whether the importance of religious ideals for believers is a good enough reason for incorporating religious ideals in public schools. Second, we will review the (in)compatibility of religious and liberal ideals in relation to the development of pupils into citizens of a liberal democracy. Third, we will address the claim that including religious ideals into the curriculum of public schools is conducive to the possibility that pupils will flourish as adults. Finally, our arguments will lead to the observation that religious ideals can indeed be included successfully in public secondary schools.

We will not be very practical or concrete in this section, but we can say something in general about the approach and aim of the inclusion of religious ideal in public schools. Grimmitt (1994) suggests that religious education can pursue three types of aims: (1) learning religion, (2) learning about religion, and (3) learning from religion. In the first instance, religion is being transmitted to pupils; in the second, religion is presented as an academic subject; in the third, educators present religions in such a way that pupils are invited to investigate the value of various religions. With regard to the inclusion of religious ideals in public schools, we suggest that the third option is to be preferred, though interpreted in both a positive and a negative sense. Positively, pupils ought to explore both the value that religious ideals have for others, but also whether or not particular religious ideals have value for themselves. Negatively, pupils ought to examine the dastardly lessons that can be learned from the pursuit of religious ideals.

\section{Religious Ideals are Important to Religious People}

In the former section we saw that reasonable pluralism does not exclude the possibility that people also refer to their religious ideals in the public domain and base their decisions on these ideals. This means that there is in principle not an argument for excluding them in the public domain of public schools either. Therefore, it does not seem unfair for religious persons to insist that their ideals be taken seriously as well. Even stronger, our analysis suggests that it is difficult to find good reasons for why in principle religious ideals should be banned from schools. Most religious parents will receive this conclusion with enthusiasm, for religious ideals are of considerable importance for believers; for some, religious ideals in the strict sense are at the core of their identity. It is therefore not surprising that many parents wish to pass on their religious ideals, both in the strict and broad sense, to their children, and want to see their ideals recognized in the public schools their children 
attend. However, it is also true that many fear any education in public schools that may undermine this faith in their children. They may believe that reasonable pluralism supplies the conditions that will subvert religious ideals in the broad sense, and consequently, religious ideals in the strict sense (thus motivating some to withdraw their children from the public schools altogether in order to have those ideals reinforced in a private religious school). ${ }^{14}$ This will be true primarily for the group of fundamentalist or orthodox parents; for the majority of religious parents, the inclusion of the ideals that have a profound meaning in their lives will be an important recognition of what they dearly value.

Fundamentalist and orthodox parents may find fault with the way in which religious ideals are addressed in public schools; they will certainly not warm to the idea that their ideals may be scrutinized in public schools. Even though education congenial to reasonable pluralism does not have as its aim to undermine the validity of religious ideals, (though it may restrict the way in which they are pursued), these groups may nevertheless be concerned that the education their children receive will have a negative effect on their beliefs (see Macedo 1995). Be that as it may, it is important to stress that religious persons not only live within their respective communities, they also are called upon to function as members of society.

\section{Religious Ideals and Citizenship of a Liberal Democracy}

We have described three types of relation between religious ideals and those of a liberal democracy and will now discuss the way in which public schools can address religious ideals that are complementary to, neutral, or opposite to, the ideal of reasonable pluralism. The focus in citizenship education will primarily be on religious ideals in the broad sense, more particularly on the religiously inspired moral, social and political ideals. However, these ideals are influenced by religious ideals in the strict sense and therefore those ideals will be part of citizenship education, too. Moreover, we would argue that understanding the motives of religious people with regard to the kind of person they think they should be is conducive to what it means to be a reasonable citizen.

Earlier we gave several examples of the positive influence of religious ideals on public life or society, like being just, caring, humble and temperate and an ideal society in which everyone is equal (because everyone is equal before God). We stated that these religious ideals are complementary to liberal democratic ideals. Inviting pupils to learn from religious ideals that cohere with liberal democratic ideals can have a twofold function: Doing so (1) fosters understanding and respect of others; and (2) pupils learn that the laws of a liberal democracy serve to protect reasonable pluralism and that religious ideals may be an important source of inspiration for some to pursue the ideals of a liberal democracy.

All pupils need to learn that there is a difference to be made between evaluating religious ideals and the way in which they are pursued. Pupils may be stimulated to discuss religious ideals and be critical about them, but they also need to learn that they have to respect the right of others to have ideals they themselves believe to be unjust, wrong or simplistic. In contrast, the way in which ideals are pursued should be scrutinized and the pursuit of ideals that infringes the harm principle should be sanctioned. Pupils also need to learn that what is of ultimate importance to them may not be the same for others, and that no one's particular conception of the good life should determine what happens in the

\footnotetext{
14 This phenomenon is perhaps more common in North America, but one certainly notices a similar phenomenon in Europe with the rapid expansion of faith schools, particularly among various minority groups. For example, concerning the recent growth in Hindu schools, see Merry and Driessen, forthcoming.
} 
public and political sphere. Pupils who have religious ideals that do not cohere with those of a liberal democracy, should learn that they are nevertheless entitled to have these, i.e. that no one may deny them their right of having and pursuing them in the private domainunless they are harmful to others. However they should also learn that in the public domain they should pursue their ideals in such a way that the effect is not negative but at least neutral in the way we have described it. Although these pupils may feel that this invites a kind of schizophrenia between their public and private life (McLaughlin 1995), they have to learn to accept that this is the best way in which people with different and even opposing views on life can live together harmoniously.

Finally, pupils will learn valuable lessons from religious ideals that are opposed to those of a liberal democracy, particularly from the ways in which the pursuit of these ideals may undermine the freedoms of others as protected under a liberal democratic constitution. That it is necessary for citizens of a liberal democracy to stay within the limits of the law, even when they believe themselves to be on the higher moral high ground, needs no defense. The evils that may emanate from the pursuit of certain religious ideals may be precisely the examples that motivate pupils to cultivate the moral dispositions necessary for strengthening deliberative democracy.

\section{Religious Ideals and the Flourishing of Pupils}

By learning from religious ideals pupils are invited to reflect on the values they take for granted, either because they are unthinkingly adopted from their parents or because they prevail in mainstream society. But why would this be important for their flourishing?

We suggest that persons are only able to flourish if they can give their own subjective interpretation to the objective goods of human well-being such as health, caring relationships, autonomy, creativity, and intellectual development. By 'interpretation' we mean that persons must come to identify with a conception of each of these in a way that personally makes sense and is worth pursuing for its own sake (De Ruyter 2007). In order to be able to discover which interpretation allows children to flourish as adults, it is important that they are introduced to different ways of life. There is not a one-to-one correspondence between what parents do or believe and find meaningful and what will enable their children to flourish. Public schools can play a significant role in furthering the possibility that children flourish when they are adults precisely by including values in the curriculum that are different from those of the families of the pupils and mainstream society (Brighouse 2005).

Yet the inclusion of alternative ways of life is not sufficient. It is important that children also learn that there are good and bad interpretations of the objective goods (De Ruyter 2007). For example, being a modest eater is arguably more conducive to one's flourishing than the extremes of obesity or anorexia; an honest friend or a loving partner are clearly much more able to contribute to human flourishing than would someone who is deceitful or narcissistic. Educators can assist children in providing them with examples of the best or ideal interpretations of objective goods. This enables children to become good judges of values themselves. Which interpretation will bring intrinsic satisfaction is something that children have to discover for themselves, but what makes their actions within this interpretation good is something that educators can teach them. If someone knows what is best, that person is able to evaluate current as well as future or alternative practices against these supreme standards. This includes religious ideals as well.

We suggest that public schools offer religious ideals in the broad sense, in order for pupils to discover if the ideals of these religions regarding, for example, sexuality or 
morality, are good for them, too. This does not mean that they have to adopt the religion itself; the ideal does not have to become a religious ideal for them, though it may be transformed into a personal ideal for their own lives. For example, the sexual ideal of chastity before marriage or fidelity during one's life-long relationship are meaningful alternatives to promiscuous alternatives found on music channels like the Box, MTV or TMF. We also stated that Christian and Islamic religious ideals normally refer to nonmaterialistic and non-competitive excellent or perfect values, and therefore, for some children, could be an antidote to the dominance of materialism and competition in mainstream society (see Burtt 2003; Conroy 2004; Merry 2007). By learning from religious ideals, pupils are invited to learn from what, to paraphrase Matthew Arnold's words, many consider to the best that has been said and thought in the world.

\section{Conclusion}

On the basis of our foregoing reflections, we conclude that it is important for public schools to incorporate religious ideals into their curricula. Concisely put, this consists of offering pupils the possibility for positive learning from religious ideals that are compatible with reasonable pluralism and for learning from the negative effects of ideals when they are pursued in ways that are detrimental to those valued in liberal democracies.

Finally, it still might be objected that our argument, including our suggestions for the way in which the religious ideals might be included, is based on liberal democratic principles and therefore we have been begging the question. This may be partly true, but we have pushed the discussion of religious toleration and reasonable pluralism much further along. Importantly, we have shown that a separation between church and state does not mean that religious ideals have no place in the public domain or that ideals should be banned from public schools. Particularly today when religion is back in the centre of the public and political discussion, but where much of the attention is negative and does little to foster mutual understanding among religious and non-religious persons, or, for that matter, among persons with different religious commitments, the current silence in public schools should be replaced with the inclusion of religious ideals. The combination of the reasons we have offered is, in our view, sufficient to draw this conclusion, and, we hope, will assist in opening a new line of debate about religion in public schools.

Open Access This article is distributed under the terms of the Creative Commons Attribution Noncommercial License which permits any noncommercial use, distribution, and reproduction in any medium, provided the original author(s) and source are credited.

\section{References}

Abbas, T. (2007). Ethno-religious identity and Islamic political radicalism in the UK: A case study. Journal of Muslim Minority Affairs, 27(3), 429-442.

Brighouse, H. (2005). Channel one, the anti-commercial principle, and the discontinuous ethos. Educational Policy, 19(3), 528-550.

Bryk, A. S., Lee, V. E., \& Holland, P. B. (1993). Catholic Schools and the Common Good. Cambridge: Harvard University Press.

Burtt, S. (2003). Comprehensive educations and the liberal understanding of autonomy. In K. McDonough \& W. Feinberg (Eds.), Citizenship and education in liberal-democratic societies. Oxford: Oxford University Press.

Callan, E. (1985). McLaughlin on parental rights. Journal of Philosophy of Education, 19(1), 111-118. 
Callan, E. (1997). Creating citizens: Political education and liberal democracy. Oxford: Oxford University Press.

Choudhury, T. (2007). The role of Muslim identity politics in radicalisation: A study in progress. London: Department of Communications \& Local Government.

Conroy, J. C. (Ed.). (1999). Catholic education: Inside out, outside in. Dublin: Lindisfarne.

Conroy, J. C. (2004). Betwixt and between. The liminal imagination, education and democracy. New York: Peter Lang.

De Jong, J., \& Snik, G. (2002). Why should states fund denominational schools? Journal of Philosophy of Education, 36(4), 573-587.

De Ruyter, D. J. (2003). The importance of ideals in education. Journal of Philosophy and Education, 37(3), 467-482.

De Ruyter, D. J. (2006). Be ye perfect? Religious ideals in education. Journal of Beliefs and Values, 27(3), 269-280.

De Ruyter, D. J. (2007). Ideals, education and happy flourishing. Educational Theory, 57(1), 23-35.

De Ruyter, D. J., \& Miedema, S. (2000). Denominational schools in the Netherlands. In M. Leicester, C. Modgil \& S. Modgil (Eds.), Spiritual and religious education; education, culture and values (Vol. 5 , pp. 133-141). London: Falmer Press.

Dwyer, J. G. (1998). Religious schools v children's rights. Cornell: Cornell University Press.

Emmet, D. (1994). The role of the unrealisable. A study in regulative ideals. New York: St. Martin's Press.

Feinberg, W. (2006). For goodness sake: Religious schools and education for democratic citizenry. New York: Routledge.

Fuller, L. L. (1969). The morality of law (revised ed.). New Haven: Yale University Press.

Gardner, R., Cairns, J., \& Lawton, D. (Eds.). (2002). Faith schools: Consensus or conflict? London: Routledge.

Grimmitt, M. (1994). Religious education and the ideology of pluralism. British Journal of Religious Education, 16(3), 133-147.

Gutmann, A. (1995). Civic education and social diversity. Ethics, 105, 557-579.

Gutmann, A. (1999). Democratic education (2nd ed.). Princeton: Princeton University Press.

Hand, M. (2004). The Problem with faith schools. Theory and Research in Education, 2(3), 343-353.

Holmes, M. (1995). Common schools for a secularist society. Canadian Journal of Education/Revue canadienne de l'éducation, 20(3), 284-296.

Husain, E. (2007). The Islamist. London: Penguin Press.

Jackson, R., Miedema, S., Weisse, W., \& Willaime, J. P. (Eds.). (2007). Religion and education in Europe: Developments, contexts and debates. Münster: Waxmann.

Leicester, M., Modgil, C., \& Modgil, S. (Eds.). (2000). Spiritual and religious education; educations, culture and values (Vol. 5). London: Falmer Press.

Levinson, M., \& Levinson, S. (2007). "Getting Religion": Religion, diversity, and community in public and private schools. In R. Curren (Ed.), Philosophy of education: An anthology (pp. 283-289). London: Blackwell.

Macedo, S. (1995). Liberal civic education and religious fundamentalism: The case of God vs. John Rawls? Ethics, 100, 468-496.

Macedo, S. (2000). Diversity and distrust: Civic education in a multicultural democracy. Cambridge: Harvard University Press.

Malik, M. (2001). Islam in Europe: Quest for a paradigm. Middle East Policy, 8(2), 100-115.

Malik, M. (2004). Muslims pluralize the West, resist assimilation. Middle East Policy, 11(1), 70-83.

March, A. (2006). Liberal citizenship and the search for an overlapping consensus: The case of Muslim minorities. Philosophy and Public Affairs, 34(4), 373-421.

Merry, M. (2005). Indoctrination, moral instruction and non-rational beliefs: A place for autonomy? Educational Theory, 4(55), 399-420.

Merry, M. (2007). Culture, identity and Islamic schooling: A philosophical approach. New York: Palgrave.

Merry, M., \& Driessen, G. (forthcoming). Integration by other means: Hindu Schools in the Netherlands.

McLaughlin, T. H. (1984). Parental rights and the religious upbringing of children. Journal of Philosophy of Education, 18(1), 75-83.

McLaughlin, T. H. (1985). Religion, upbringing and liberal values: A rejoinder to Eamonn Callan. Journal of Philosophy of Education, 19(1), 119-127.

McLaughlin, T. H. (1995). Liberalism, education and the common school. Journal of Philosophy of Education, 29(2), 239-256.

McLaughlin, T. H. (1996). The distinctiveness of Catholic education. In T. H. Mclaughlin, J. M. O'Keefe \& B. O'Keeffe (Eds.), The contemporary Catholic school: Context, identity and diversity (pp. 136-154). London: Falmer. 
Noddings, N. (1993). Educating for intelligent belief or unbelief. New York: Teachers College Press.

Nord, W. (1995). Religion and American education: Rethinking a national dilemma. Chapel Hill: University of North Carolina Press.

Pennock, R. (2007). Should creationism be taught in the public schools? In R. Curren (Ed.), Philosophy of education: An anthology (pp. 539-552). London: Blackwell.

Rawls, J. (1987). The idea of an overlapping consensus. Oxford Journal of Legal Studies, 7(1), 1-25.

Rawls, J. (1989). The domain of the political and overlapping consensus. New York University Law Review, 64(2), 233-255.

Rawls, J. (1993). Political liberalism. New York: Columbia University Press.

Rescher, N. (1987). Ethical idealism. An inquiry into the nature and function of ideals. Berkeley: University of California Press.

Rosenblith, S. (2008). Beyond coexistence: Toward a more reflective religious pluralism. Theory and Research in Education, 6(1), 107-121.

Rosenblith, S., \& Priestman, S. (2004). Problematizing religious truth: Implications for public education. Educational Theory, 54(4), 365-380.

Salili, F., \& Hoosain, R. (Eds.). (2006). Religion and multicultural education, vol. 4 in series research in multicultural education and international perspectives. Greenwich: Information Age Publishing.

Spiecker, B., De Ruyter, D. J., \& Steutel, J. W. (2006). Taking the right to exit seriously. Theory and Research in Education, 4(3), 313-326.

Strike, K. (2007). Common schools and uncommon conversations: Education, religious speech and public spaces. Journal of Philosophy of Education, 41(4), 693-708.

Spinner-Halev, J. (2000). Surviving diversity. Religion and democratic citizenship. Baltimore: The John Hopkins University Press.

Tarazi, N. (1987). Who is teaching your child? Islamic Horizons, 30(4), 40-43.

Yousif, A. (2000). Islam, minorities and religious freedom: A challenge to the modern theory of pluralism. Journal of Muslim Minority Affairs, 20(1), 29-41. 